DOI: https://doi.org/10.47405/mjssh.v5i2.369

\begin{tabular}{|c|c|}
\hline 4 & Malaysian Journal of Social Sciences and Humanities (MJSSH) \\
\hline $\begin{array}{l}\text { Malaysian Journal of } \\
\text { Social sciences and }\end{array}$ & Volume 5, Issue 2, February 2020 \\
\hline (MJ-SSH) & e-ISSN : 2504-8562 \\
\hline & $\begin{array}{l}\text { Journal home page: } \\
\text { www.msocialsciences.com }\end{array}$ \\
\hline
\end{tabular}

\title{
Pengaruh Inovasi Teknologi, Peranan Pentadbir dan Kesediaan Guru Terhadap Profesionalisme Keguruan Sekolah Luar Bandar di Sabah
}

\author{
Muliyati Timbang1, Abdul Said Ambotang1 \\ 1Fakulti Psikologi dan Pendidikan, Universiti Malaysia Sabah (UMS) \\ Correspondence: Muliyati Timbang (muliyati7272@yahoo.com.my)
}

\begin{abstract}
Abstrak
Kajian semasa menunjukkan pengaruh Inovasi Teknologi, peranan pihak pentadbir sekolah serta kesedaran guru dalam peningkatan profesionalisme keguruan. Berdasarkan latar belakang tersebut kajian ini bertujuan untuk melihat hubungan Inovasi teknologi, peranan pentadbir dan kesediaan guru terhadap peningkatan profesionalisme keguruan khususnya sekolah luar bandar di Sabah. Fokus kajian adalah berdasarkan rekabentuk teknologi, peranan pentadbir dan kesediaan guru terhadap profesionalisme keguruan di Sabah. Teori dan model yang digunakan sebagai panduan kajian antaranya ialah Teori penyebaran inovasi, Teori TMK dan keterselesaian tugas, Teori pembelajaran sosial, Teori maslow, Model penggunaan Teknologi, Model TAM (Technology Acceptance Modal) Model professional Brante. Kajian ini mengaplikasikan metodologi tinjauan, Rekabentuk penyelidikan yang digunakan ialah penyelidikan deskriptif jenis tinjauan. Ujian deskriptif yang digunakan ialah ujian min, kekerapan dan peratusan manakala ujian inferansi akan menggunakan ujian regrasi, kolerasi, ujian -t dan ujian ANOVA. Sample kajian terdiri daripada 372 orang guru yang bertugas di sekolah luar bandar di negeri Sabah. Soalan kajian akan dianalisis menggunakan program Stastical Package for the social science (SPSS) versi 22.0.
\end{abstract}

Kata kunci: pengaruh inovasi teknologi, peranan pentadbir, kesediaan guru, peningkatan profesionalisme keguruan

\section{Influence of Innovation, Role of Administrations and Teacher Readiness of the Rural Education Professionalism of Rural Schools in Sabah}

\begin{abstract}
The current study shows the influence of technology innovation, the role of school administrators and teachers in increasing awareness of professionalism in teaching. Based on this background, this study aimed to examine the relationship between technology innovation, the role of administrator and teacher readiness to increase professionalism in teaching, especially rural schools in Sabah. The focus of the study is based on the design of technology, the role of administrator and teacher readiness to professionalism in Sabah. Theories and models used as a study guide which is spreading innovation theory, the theory of TMK and keterleselasian duties, social learning theory, theory of Maslow, the use of the model, Model TAM (Technology Acceptance Capital) Brante professional model. This study applies the methodology of the survey, research design used is descriptive research type review. Descriptive test used is a test of mean, frequency and percentage while inferansi test will use the test regression, correlation, tes-t and ANOVA. The sample consisted of 372 teachers who work in schools
\end{abstract}


in rural areas of the state. Question of the study will be analyzed using the program stastical Package for the Social Sciences (SPSS) version 22.0.

Keywords: technological innovation, the role of administrator, teacher preparedness, increased professionalism in teaching

\section{Pengenalan}

Pada masa kini, adalah tidak menjadi satu kejutan apabila melihat guru-guru dan pentadbir sekolah menggunakan komputer untuk menyimpan, memproses dan mempersembahkan data atau hasil kerja masing-masing. Pada abad ke 21 ini, peranan guru bukan hanya dilihat semasa proses pengajaran dalam pembelajaran berlansung. Tugas guru telah meluas sehingga ke 'medan' pentadbiran dan pengurusan sekolah ke arah kualiti. Bertitik tolak daripada kenyataan ini, ternyata guru masa kini berperanan besar merealisasikan pengurusan organisasi berkualiti disamping perlaksanan dan penyebaran kurikulum di kelas berasaskan teknologi (Abdul. Ghani et. Al, 2005).

Bagi meningkatkan profesionalisme guru, Kerajaan Malaysia telah membelanjakan beribu-ribu ringgit untuk menyediakan dan membekalkan infrastruktur dan perkakasan teknologi (desktop, komputer, komputer riba, LCD projector, pencetak, CD courseware dan lain-lain) kepada semua sekolah di Malaysia untuk program Pengajaran dan Pembelajaran. Latihan perkembangan Profesionalisme Guru turut disediakan untuk melatih guru-guru menggunakan peralatan dan perkakasan teknologi serta software yang telah dibekalkan. Guru-guru juga telah didedahkan dengan menggunakan software English Essential in Teaching and Learning untuk pengurusan tugas sekolah dan coraldraw untuk menghasilkan bahan pengajaran dan pembelajaran.

Maklumat Teknologi untuk guru-guru adalah merupakan usaha kerajaan secara keseluruhan dalam meningkatkan profesionalisme keguruan. Namun, bagi mencapai tahap profesionalisme keguruan yang tinggi, tugas ini tidak seharusnya diserah seratus peratus kepada pihak kerajaan amnya. Sebagai seorang guru yang terlatih secara profesional, sebaik sahaja melangkah kaki keperkhidmatan keguruan, guru harus sentiasa mengembangkan diri dan menganggap ini merupakan permulaan cabaran hidup dalam dunia kerjaya sebagai pendidik. Guru berhadapan dengan pelbagai bentuk perubahan. Kejayaan dan kelestarian seseorang guru dalam profesionnya adalah bergantung kepada kesediaan guru untuk memajukan diri dan profesionalisme keguruan (Pang, 2010).

Pelbagai aktiviti dan program pendidikan boleh dilakukan untuk meningkatkan profesionalisme seseorang guru. Antaranya adalah seperti meningkatkan kemahiran-kemahiran tertentu yang melibatkan profesionalisme keguruan iaitu berkursus, mengikuti seminar, menyambung pembelajaran ke peringkat Ijazah Perguruan, peringkat Sarjana sekaligus ke peringkat kedoktoran sambil bekerja atau cuti separuh masa untuk melanjutkan pelajaran dan menanam sikap yang positif terhadap kerja atau tugas di sekolah di samping meningkatkan profesionalisme keguruan. Guru bukan hanya dilihat semasa proses pengajaran dalam pembelajaran berlansung. Tugas guru telah meluas sehingga ke 'medan' pentadbiran dan pengurusan sekolah ke arah kualiti. Bertitik tolak daripada kenyataan ini, ternyata guru masa kini berperanan besar merealisasikan pengurusan organisasi berkualiti di samping perlaksanaan dan penyebaran kurikulum dikelas berasaskan teknologi (Kementerian Pendidikan Malaysia, 2000).

Berteraskan kepada kurikulum sekolah menengah yang disemak semula, juga mementingkan kebolehan para pelajar menggunakan teknologi dengan cara yang berkesan dalam pembelajaran. Ini jelas menunjukkan dalam era perkembangan teknologi ini, penggunaan teknologi seperti komputer, kalkulator saintifik, perisian pembelajaran interaktif dan dinamik, merupakan elemen yang penting dalam pengajaran dan pembelajaran. Ia bertujuan untuk mempersiap dan memperkasakan pendidik dalam menghadapi cabaran di masa hadapan. Selaras dengan kandungan dan harapan Falsafah Pendidikan Kebangsaan, iaitu memperkembangkan potensi individu secara menyeluruh dari aspek intelek, rohani, emosi dan jasmani yang bertujuan melahirkan masyarakat yang berilmu pengetahuan, 
berketrampilan, berakhlak mulia, bertanggungjawab dan berkeupayaan dalam mencapai kesejahteraan diri dan seterusnya memberikan sumbangan terhadap keharmonian dan kemakmuran keluarga, masyarakat dan Negara (Kementerian Pendidikan Malayasia, 2000).

\section{Latar Belakang Kajian}

Teknologi yang digunakan dalam pengurusan sekolah secara tradisional adalah seperti penggunaan telefon, faks, mesin fotostet, kertas, fail dan lain-lain. Semua teknologi tersebut dikatakan telah banyak membantu guru dan pentadbir sekolah merekod segala urusan murid di sekolah. Selain itu, bahan proses pengajaran dan pembelajaran guru di dalam kelas secara tradisional hanya kertas, buku teks, papan tulis dan kapur sahaja. Akan tetapi, zaman semakin berubah, jumlah penduduk semakin ramai dan teknologi semakin berkembang dengan pesat. Keadaan ini seterusnya memaksa sekolah berubah kepada keadaan yang lebih selesa (Abd. Ghani et.al, 2005).

Menurut Rahmat (2005) pada era globalisasi kini, dilihat bahawa teknologi telah menjadi pelengkap kepada tugasan harian mereka di sekolah setiap hari. Kementerian Pendidikan Malaysia turut memperkenalkan TMK dalam pengurusan di pejabat- pejabat pendidikan dan khusunya di sekolah seperti keadah penyimpanan data melalui EMIS (Education Management Information System). Pendaftaran murid untuk menduduki peperiksaan contohnya Ujian Penilaian Sekolah Rendah (UPSR), Sijil Pelajaran Malaysia (SPM) dan Sijil Tinggi Persekolahan Malaysia (STPM) turut dilakukan melalui program komputer ini sejak tahun 2001. Pada tahun 2002, penggunaan TMK diperkenalkan program SMM (Sistem Maklumat Murid). Program ini memasukkan dan menyimpan data murid termasuk data kesalahan disiplin murid melalui program komputer.

Pada era globalisasi ini kementerian pendidikan juga telah memperkembangkan lagi aspek ilmu dengan memperkenalkan LINUS di sekolah rendah agar murid-murid dapat menguasai 3M iaitu membaca, menulis dan mengira seterusnya lagi MBMMBI turut diperkenalkan dikalangan para pendidik amnya. Seterusnya Kementerian Pendidikan memperkenalkan lagi Instrumen Penilaian Bersepadu Pegawai Perkhidmatan Pendidikan (PBPPP) untuk menilai perkhidmatan para guru sama ada dalam pengajaran dan pembelajaran dan aktiviti khidmat sosial sama ada dalam dan luar sekolah. Kesemua program ini memerlukan kepakaran Teknologi masa kini demi untuk melicinkan lagi aktiviti kerja di kalangan para guru. (Pang, 2010).

\section{Masalah Kajian}

Menurut Steven dan Paul (2006) bidang Pendidikan telah 'menghasilkan' ramai pendidik yang digelar sebagai guru dan berkhidmat di jabatan pendidikan (sekolah). Namun, adakah semua guru yang bertugas dapat menunjukkan profesionalisme keguruan mereka. Istilah profesionalisme dalam bidang keguruan telah menjadi perhatian dan didebatkan oleh pelbagai pihak. Dalam perdebatan ini, banyak kajian profesionalisme keguruan dengan sedihnya membuat kenyataan bahawa tugas mengajar "tidak begitu" professional dari segi kesedian mengajar. John Goodland dalam bukunya Teacher for Our nation's Schools (1990) menulis "The conditions necessary to a profession simply have not been a part of either teacher education or the teaching enterprise" (Steven and Paul, 2006). Ini bermakna kewibawaan guru untuk mencapai tahap professional tidak cukup tinggi dan dipersoalkan.

Profesionalisme keguruan tercabar lagi apabila terdapat sesetengah pengkritik yang membandingkan profesion guru dengan profesion peguam, doktor, jurutera dan lain-lain. Perbandingan dibuat berdasarkan kepada nilai kerja mereka. Bidang profesionalisme mementingkan nilai, kepercayaan dan sikap dalam tugas mereka untuk memenuhi kehendak pelanggan. Justeru, profesion guru terus dipersoal. Profesion guru dikatakan akan membuat apa yang diarah. Mereka tidak diberi peluang untuk mengembangkan inisiatif individu yang mungkin boleh 'menggoncangkan kapal' organisasi sekolah. Terdapat juga kritikan mengatakan profesionalisme keguruan jarang berusaha untuk meningkatkan kualiti perkhidmatan. Mereka lebih membimbangkan tentang kenaikan gaji, keadaan kerja dan peluang kerjaya dalam professional pendidikan (Carr, 2000). Justeru itu guru terus dilabel 'unprofessional'. 
Menurut Kaori dan Motonori (2006), kreteria profesionalisme keguruan berbeza-beza mengikut negara masing-masing. Di negara Jepun program penilaian prestasi guru telah diwujudkan sejak permulaan zaman Konservatisma dan Tentangan Liberal pada tahun 1948. Di bawah skim ini, pengetua akan menilai kerja setiap guru berdasarkan 46 kriteria seperti pengurusan bilik darjah, bimbingan murid dan kerja perkeranian. Dilihat kriteria diatas tidak mempunyai jarak perbezaan yang besar. Namun, perubahan globalisasi kini telah mencabar profesion guru. Banyak isu dan laporan yang disiarkan dalam media massa telah menjatuhkan martabat profesion keguruan. Guru dikatakan mengalami keadaan yang 'tenat' akibat terlalu banyak tanggungjawab telah diberikan. Guru terpaksa melaksanakan kerja-kerja dari segi perancangan untuk mengajar, pengajaran, kerja-kerja perkeranian, kegiatan kokurikulum, menghadiri mesyuarat dan melaksanakan kerja ad hoc. Keadaan ini menyebabkan berlakunya ketidak puasan bekerja dikalangan guru kerana merasa diri mereka dalam kelesuan. Perkara ini amat serius kerana ia akan menyumbang kepada stress dan burn out dikalangan guru di sekolah.

\section{Objektif Kajian}

Tujuan kajian ini adalah untuk meninjau pengaruh inovasi teknologi, peranan pentadbir dan kesediaan guru dalam peningkatan profesional keguruan di sekolah luar bandar di Sabah. Aspek profesionalisme yang akan dilihat ialah dari segi kemahiran profesionalisme dan sikap profesionalisme seorang guru. Oleh yang demikian, kajian ini bertujuan untuk melihat hubungan dan pengaruh inovasi teknologi, peranan pentadbir dan kesediaan guru dalam peningkatan profesionalisme keguruan.

Berdasarkan tujuan kajian yang dinyatakan di atas, objektif kajian ini adalah untuk:

i. Mengenal pasti tahap inovasi teknologi, peranan pentadbir dan kesediaan guru sekolah luar bandar di Sabah.

ii. Mengenal pasti tahap peningkatan profesionalisme keguruan sekolah luar bandar di Sabah.

iii. Mengenal pasti perbezaan peningkatan Profesionalisme keguruan sekolah luar bandar berdasarkan faktor demografi.

iv. Mengenal pasti hubungan inovasi teknologi dengan peningkatan profesionalisme keguruan sekolah luar bandar di Sabah.

v. Mengenal pasti hubungan antara peranan pentadbir dengan peningkatan profesionalisme keguruan sekolah luar bandar di Sabah.

vi. Mengenal pasti hubungan antara kesediaan guru dengan peningkatan profesionalisme keguruan sekolah luar bandar di Sabah.

vii. Mengenal pasti pengaruh faktor-faktor inovasi teknologi, peranan pentadbir dan kesediaan guru terhadap peningkatan profesionalisme keguruan sekolah luar bandar di Sabah.

\section{Tinjauan Literatur}

Kajian ini adalah bertujuan untuk meninjau pengaruh inovasi teknologi, peranan pentadbir dan kesediaan guru di sekolah terhadap peningkatan profesionalisme keguruan dalam kalangan guru di sekitar sekolah luar bandar di Sabah. Sebelum meneroka pengaruh, kajian ini akan meninjau terlebih dahulu hubungan antara inovasi teknologi sekolah dengan profesionalisme keguruan dalam kalangan guru di sekolah luar bandar di daerah Tawau. Kajian ini akan cuba mengenal pasti inovasi teknologi sekolah yang semakin kian berkembang di dalam bidang pendidikan turut juga dapat menyumbang kepada perkembangan profesionalisme keguruan. Elemen professional keguruan yang akan ditinjau telah digariskan iaitu perkembangan akan dilihat dari aspek kemahiran dalam menjalankan tugas dan sikap terhadap tugas. Kajian ini penting agar dapat membantu guru-guru yang 'burn out' atau dibebani tugas. Kepentingannya dapat dilihat apabila inovasi Teknologi sekolah merupakan alternative baru yang boleh meringankan beban guru. Dengan cara ini, guru dapat meningkatkan lagi semangat memajukan diri seterusnya profesionalisme keguruan. 


\section{Konsep Profesionalisme}

Menurut Carr (2000), dalam Pang Shin Lu (2010), beliau menggariskan 5 kriteria untuk profesionalisme iaitu profesion yang khidmat kepada orang awam, prefesion yang melibatkan teori dan praktikal, profesion yang mempunyai dimensi etika yang jelas, profesion yang memerlukan organisasi dan peraturan yang bertujuan untuk mengambil kakitangan dan disiplin serta profesion yang memerlukan individu yang mempunyai tahap autonomi yang tinggi (membuat keputusan sendiri dan kerja yang efektif). Selain itu, beliau menambah lagi bahawa profesionalisme turut perlu mempunyai kemahiran teknikal dan nilai moral yang tinggi ketika melaksanakan tugas. Kemahiran yang dimaksudkan seperti kemahiran berkomunikasi dan kemahiran kepimpinan. Manakala bagi nilai moral pula, adalah penting bagi seseorang individu mempunyai sikap dan tahap pertimbangan yang tinggi.

Beck dan Murpy (1996) dalam Meher (2003) mendefinisikan profesionalisme sebagai "a complex construct, one that includes numerous components, such as commitment, satisfaction, and efficacy." Ini bermakna profesionalisme turut melibatkan komitmen, kepuasan dan efikasi seseorang ketika bekerja. Menurut Eraut (1994) pula mengangap profesionalisme merupakan kerja khidmat awam seperti guru dan kerja sosial mempunyai satu kepentingan bersama iaitu pengetahuan dan bidang khusus serta mempunyai kod etika masing-masing.

Pada dekad ini, profesion perguruan sentiasa dipertikaikan., namun konsep pendidikan dan guru masih dipertahankan kerana melihat mereka memegang akauntabiliti terhadap murid, ibu bapa dan masyarakat (Carr, 2000). Menurut Carr, (2000), walaupun profesion guru tidak sama dengan peguam atau doktor tetapi mereka turut mempunyai etika dan dilengkapi dengan teori-teori pembelajaran dan diaplikasikan di dalam bilik darjah. Tambahan lagi, guru sentiasa dilengkapi dengan kemahirankemahiran tertentu dan sering meningkatkan lagi melalui program perkembangan guru melalui kursus, seminar, bengkel dan hal-hal pendidikan yang lain.

\section{Konsep Inovasi}

Konsep inovasi diperjelaskan dalam Wikipedia yang bermaksud melakukan sesuatu dengan kaedah yang baru. Inovasi merujuk kepada peningkatan idea, menyeluruh dan mengakibatkan perubahan besar dalam pemikiran, produk, proses dan organisasi. Maka dapat dilihat inovasi itu membawa kepada perubahan positif, yang membolehkan seseorang atau produktiviti menjadi lebih baik.

Rahmad (2005) dalam penulisannya Inovasi IT dalam Pengurusan Pendidikan merumuskan bahawa inovasi merupakan satu proses penambahbaikkan kepada pengeluaran sesuatu produk atau peningkatan sesuatu perkhidmatan, dengan menggunakan idea-idea baru. Proses ini dibuat untuk memenuhi kehendak pelanggan yang seterusnya akan meningkatkan keuntungan sesebuah organisasi.

\section{Konsep Teknologi}

Istilah teknologi mempunyai takrifan yang amat luas sekali. Wikipedia mentakrifkan teknologi ialah pembangunan dan penggunaan alatan, mesin, bahan dan proses yang membantu manusia menyelesaikan masalah. Contohnya seperti gunting, pemotong kertas atau mesin yang lebih kompleks seperti sistem angkasa lepas dan pencetak. Selain itu, teknologi turut dikaitkan dengan bidang ekonomi yang mana teknologi dilihat sebagai tahap pengetahuan semasa dalam menggabungkan sumber bagi menghasilkan produk yang dikehendaki. Oleh yang demikian, bolehlah dikatakan bahawa teknologi merupakan satu proses yang boleh mengubah cara hidup manusia.

Menurut Musa (2002), teknologi bermakna satu cara, peralatan, bahan atau perisian untuk melakukan, membuat atau membina sesuatu. Beliau juga menambah bahawa teknologi merupakan kaedah dan cara (means) yang pada keseluruhannya digunakan untuk mengadakan objek yang perlu bagi kehidupan dan keselesaan manusia. Oleh itu, manusia sentiasa berusaha mencari idea untuk menghasilkan teknologi yang seterusnya membolehkan manusia melakukan kajian dan pengubahsuaian dalam sesuatu perkara. Beliau juga turut bersetuju bahawa daripada pengalaman pada masa lalu telah menunjukkan bahawa manusia berubah mengikut perubahan kemajuan teknologi dari masa kesemasa. 


\section{Teknologi Maklumat dan Komunikasi}

Menurut Musa, (2002) teknologi Maklumat dan Komunikasi berasal dari perkataan teknologi maklumat dan teknologi komunikasi. Mengikut Musa (2002), teknologi maklumat secara amnya merupakan kaedah, peralatan dan perisian yang terlibat dalam proses penjanaan maklumat, pengumpulan maklumat, pemprosesan maklumat, pengurusan maklumat, penyebaran maklumat dan penyimpanan maklumat. Maklumat yang dimaksudkan adalah dalam pelbagai bentuk dan tidak terhad kepada tulisan dan teks sahaja. Contohnya seperti gambar, bunyi atau data adalah maklumat. Maka, teknologi berupaya mengumpulkan semua maklumat ini dan disebarkan kepada semua dalam pelbagai bentuk. Komputer pula yang sering dikaitakn dengan teknologi maklumat. Ini adalah kerana keupayaan komputer sebagai satu alat atau perkakasan yang boleh menjana, mengumpul, menyebar, mmemproses dan menyimpan maklumat dengan cepat, berkesan dan efisien.

\section{Pengaruh Inovasi TMK dalam Pengurusan Pendidikan}

Pembaharuan Teknologi dalam pengurusan organisasi pendidikan telah berkembang maju dalam bidang pendidikan pada masa kini. Secara umumnya, inovasi Teknologi dalam pengurusan pendidikan di sekolah terbahagi kepada 3 peringkat iaitu ;

Peringkat 1: Sekolah memperoleh komputer sendiri untuk kegunaan pejabat.

Peringkat 2: Kementerian Pendidikan Malaysia (KPM) membekalkan komputer kepada sekolah untuk meningkatkan mutu Pengajaran dan Pembelajaran

Peringkat 3: Saling bergantung antara sekolah, jabatan dan kementerian berkenaan terhadap aplikasi IT dalam sistem pengurusan (Rahmad, 2005).

Dengan ini, inovasi teknologi akan memberi sumbangan besar terhadap perubahan dalam organisasi pendidikan. Di antaranya seperti perubahan dalam struktur pengurusan organisasi pendidikan dan anjakan struktur pengurusan daripada 'hierarki berasaskan kefungsian' kepada struktur pengurusan berasaskan tugas atau proses.

\section{Teori Penyebaran Inovasi (Diffusion of Innovation Theory)}

Menurut Bates et al., (2007), Perry mendefinisikan teori penyebaran dalam bidang pendidikan sebagai satu proses melalui beberapa inovasi yang berkaitan dengan sistem sosial. Beliau menegaskan bahawa setiap individu memainkan peranan dan pengaruh sosialnya untuk proses penyebaran ini. Rogers juga merupakan salah seorang pengkaji teori penyebaran inovasi tetapi beliau lebih tertumpu kepada pendekatan teoritikal. Teori yang dikemukakan oleh Rogers terbahagi kepada 3 komponen utama iaitu proses membuat keputusan inovasi, ciri-ciri inovasi dan ciri-ciri pengguna inovasi.

Komponen satu merujuk kepada langkah-langkah yang telah diambil oleh individu tertentu untuk peka kepada inovasi. Ini boleh dilakukan dengan melihat kepada hubungan sikap pengguna dengan inovasi bagi membolehkan keputusan dibuat sama ada perlu diimplementasikan atau tidak. Komponen kedua pula merujuk kepada ciri-ciri ini seperti kesesuaian, kerumitan, keboleh perhatian, kebaikan dan keboleh ujian (compatibility, complexity, observability, relative advantage and trilibility). Rogers mendifinisikan komponen ketiga kepada tiga tahap iaitu sosio-ekonomi, nilai personaliti dan tingkah laku komunikasi.

\section{Teori Penggunaan TMK dan Keterselesaian Tugas}

Teori ini dikemukakan untuk melihat secara ringkas kegunaan TMK dan bagaimana penggunaan TMK boleh digunakan secara meluas melalui perbandingan. Rajah 1 menunjukkan bagaimana TMK digunakan untuk menyelesaikan satu tugas dan beberapa tugas secara berterusan. 


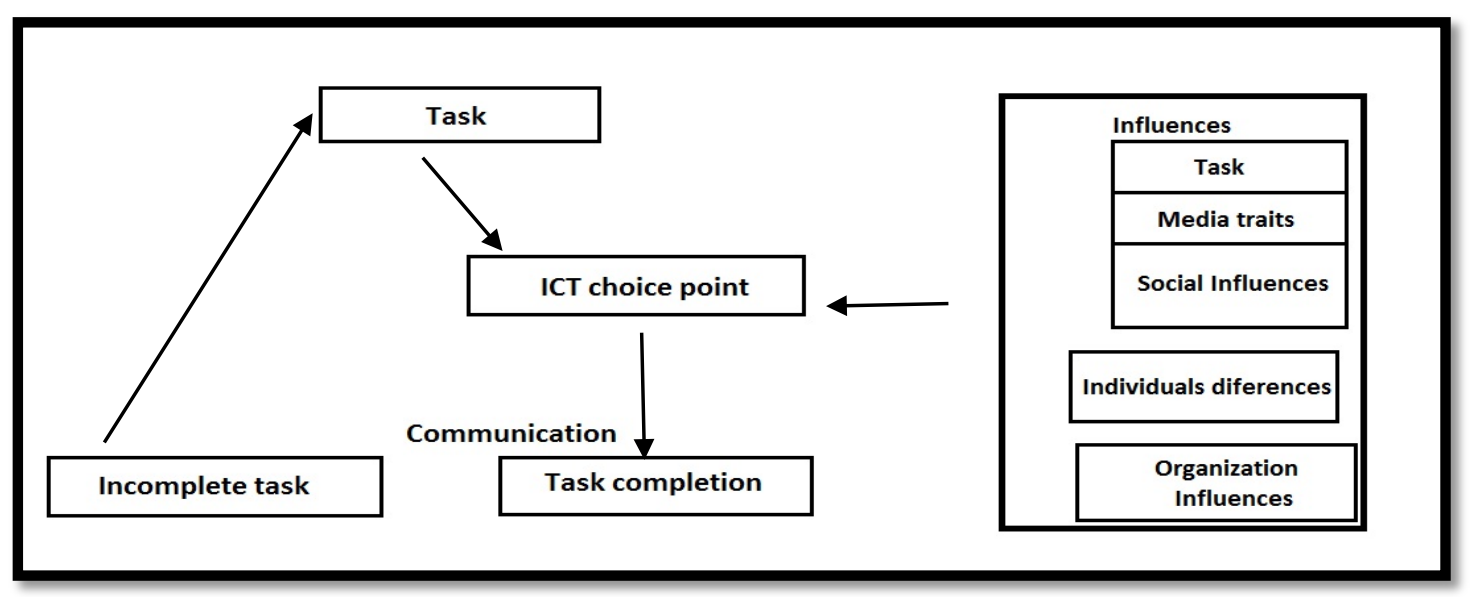

(Sumber: Steven 2007)

Menurut Steven (2007), kebanyakan penyelidik tidak melihat penggunaan TMK adalah satu proses tetapi hanya fokus secara linear di bahagian kiri Rajah 1 di atas Tugas, ciri-ciri media, pengaruh sosial, pengaruh individu dan pengaruh organisasi akan mempengaruhi individu untuk menerima penggunaan TMK bagi menyelesaikan tugasnya. Dalam rajah 1 menunjukkan dengan menggunakan TMK pelbagai tugas dapat diselesaikan dalam masa yang singkat. Maka, teori ini amat sesuai dalam kajian ini kerana melihat tugas guru yang pelbagai dalam bidang pendidikan terutamanya ketika berada di sekolah dan di dalam kelas.

\section{Teori Pembelajaran Sosial}

Diketahui bahawa seseorang individu yang professional perlu mempunyai sifat pembelajaran secara berterusan (sepanjang Hayat). Teori ini melibatkan tiga elemen iaitu proses individu, persekitaran dan tingkah laku. Proses individu merupakan motivasi intrinsik seseorang, persekitaran merujuk kepada rangsangan luaran dan tingkah laku aksi individu itu sendiri (Woolfolk, 2001). Melalui teori ini, individu akan saling mempengaruhi untuk mempelajari sesuatu yang baru bagi meningkatkan pengetahuan. Dengan ini, setelah mengadaptasikan inovasi TMK di sekolah, guru-guru akan cuba mempengaruhi guru-guru lain untuk menggunakan TMK bagi mencapai profesionalisme keguruan yang lebih tinggi.

\section{Teori Maslow}

Teori Maslow menerangkan bahawa setiap individu mempunyai keperluan masing-masing supaya mempunyai satu kuasa untuk menolak individu tersebut membuat sesuatu kerja dengan rela hati. Setiap individu mempunyai hieraki keperluan dari rendah hingga mencapai puncak yang paling tinggi, bentuk piramid. Contohnya inovasi Teknologi dan hubungannya dengan kemahiran dan sikap guru dalam meningkatkan profesionalisme keguruan. Dengan adanya inovasi setiap individu yakni guru berusaha dan berubah untuk terus maju dalam bidang ICT ini, samada dalam kehidupan seharian mahupun dalam kerjaya sebagai seorang guru. Dekad ini penggunaan TMK dalam kehidupan dan kerjaya sebagai seorang guru adalah sangat penting. 


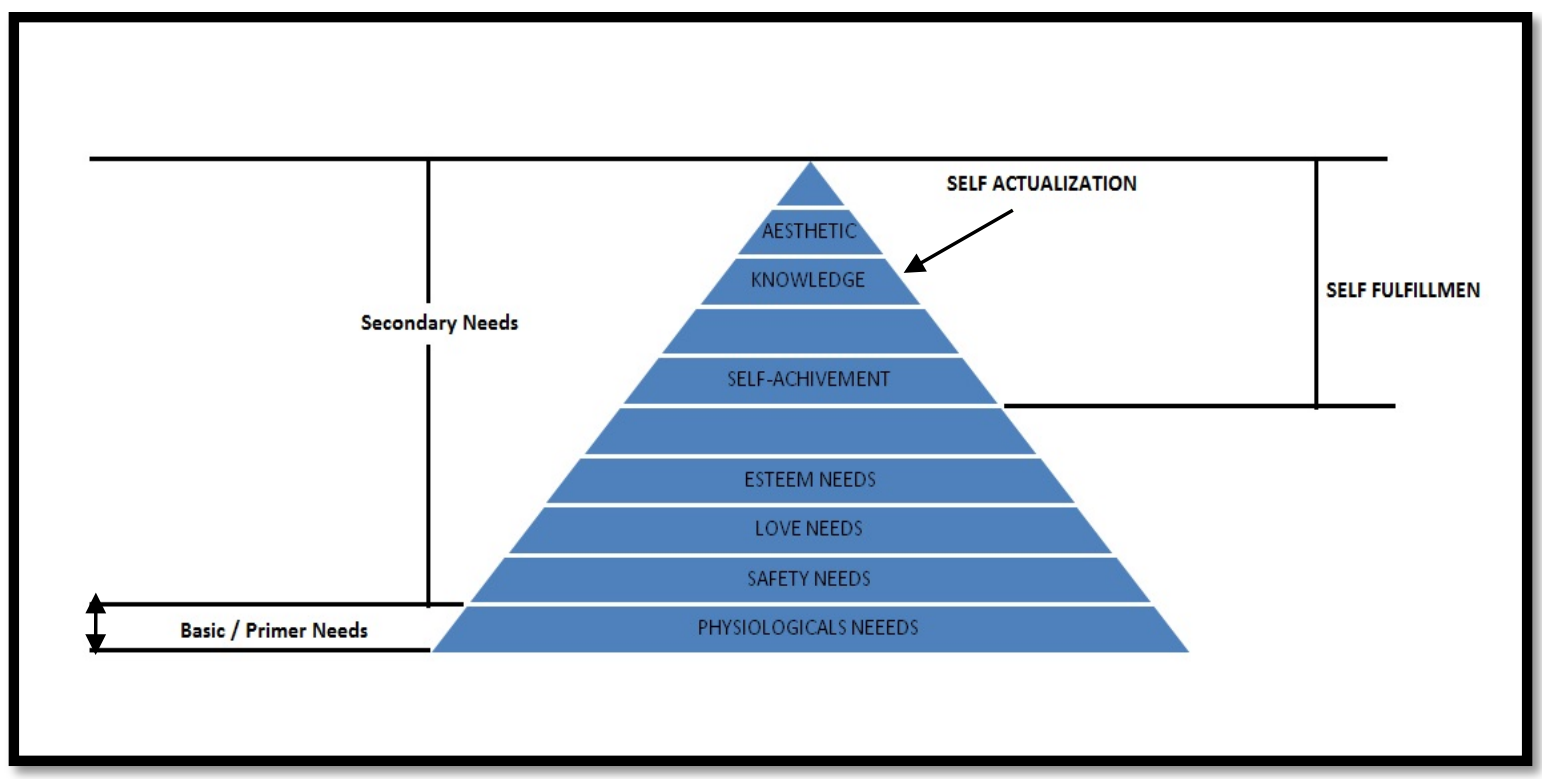

Sumber: Maslow (Woolfolk, 2001)

Setiap perubahan yang berlaku perlulah selaras dengan teori ini supaya individu itu dapat meningkatkan kepuasan bekerja seterusnya menanam minat dan dapat meningkatkan profesionalisme keguruan.

\section{Model}

Menurut Bates et. al., (2007), model ini merupakan gabungan Teori Penyebaran Inovasi dan Teori Pembelajaran Sosial. Model Marcus menggariskan kepentingan tingkah laku inovasi dengan fenomena yang lain. Komunikasi merupakan salah satu komponen yang menyebarkan inovasi kepada pengguna berpotensi yang lain. Ankem menjelaskan faktor-faktor penerimaan sesuatu inovasi adalah seperti berikut, 'pengorbanan' diri individu dan institusi, kebolehan untuk mendapatkan sumber (wang, peralatan, latihan, masa, pengalaman dan kemahiran yang berkaitan) dan 'nilai' kepada inovasi. (Bates, Manuel dan Oppenheim, 2007). Faktor-faktor di atas perlu diambil kira supaya dapat mengoptimumkan pengaplikasian inovasi ini.

\section{Model Penggunaan Teknologi}

Model Penggunaan Teknologi yang lebih menfokus kepada implementasi ICT telah banyak diamalkan di sekolah-sekolah umumnya di seluruh dunia, khasnya di Malaysia. Model ini adalah diaplikasi daripada Model Kejuruteraan yang diperkenalkan oleh Laudon dan Laudon (1998) iaitu lebih memfokus kepada automasi dan rasional. 
Rajah 3: Model Implementasi ICT Dalam Pengurusan Sekolah

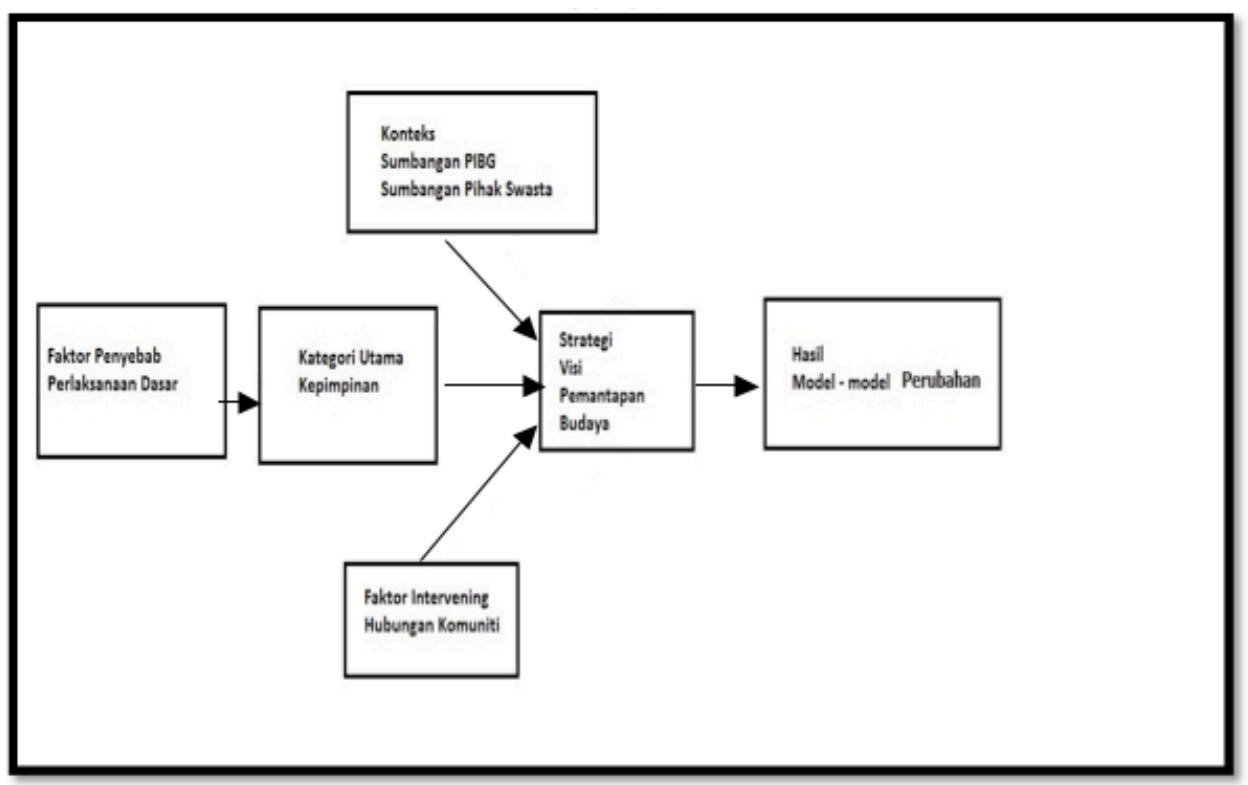

(Sumber: Yuen, law dan Wong, 2003)

Berdasarkan kepada Model pada Rajah 3, dapat diperhatikan bahawa implementasi TMK di sekolah adalah memerlukan sumbangan dari PIBG, pihak swasta atau komuniti, perubahan kearah inovasi TMK dapat dilakukan demi untuk kebaikan organisasi.

\section{Kerangka Konseptual Kajian}

Berdasarkan kepada objektif kajian, Beberapa skop atau aspek akan diambil kira memperhalusi kajian ini. Dengan itu, kerangka konseptual kajian adalah gambaran kepada kajian yang akan dijalankan nanti, berikut kerangka kajian dibina;

Rajah 5: Kerangka Konseptual Kajian

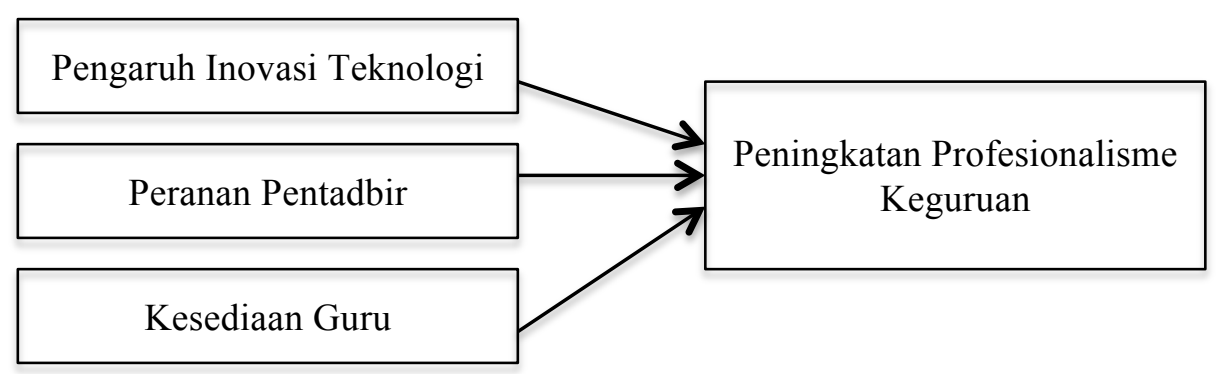

\section{Rumusan}

Demi mencapai matlamat Wawasan 2020 dan mewujudkan masyarakat bermaklumat, maka inisiatif untuk mengimplimentasikan teknologi dalam pengurusan sekolah dan pengajaran dan pembelajaran (PdP) menjadi satu keperluan dalam bidang pendidikan pada masa kini. Malah, Kementerian Pelajaran Malaysia mula mengaplikasikan dan membudayakan teknologi dalam pengurusan organisasi sekolah. Pembangunan Teknologi dalam pendidikan pada masa hadapan adalah bermatlamat untuk meningkatkan pembangunan infarstruktur teknologi, memperluaskan akses kemudahan Teknologi, 
memperluaskan kurikulum berasaskan Teknologi, meningkatkan pengetahuan dan kemahiran TMK di kalangan murid, tenaga pengajar dan personel KPM, meningkatkan penggunaan teknologi dalam pengurusan pendidikan dan sebagainya.

Maka dapat dilihat, kini kerjaya dalam bidang pendidikan tidak begitu mudah. Keupayaan profesion guru bukan hanya dilihat di dalam kelas tetapi merebak ke pentadbiran dan pengurusan tugas di sekolah. Kewibawaan guru pula sentiasa tercabar apabila berlakunya penghijrahan inovasi teknologi ke dalam sekolah dan perlu menghadapi generasi murid yang baru dari masa ke semasa. Oleh yang demikian, guru perlu sentiasa peka kepada keperluan untuk mempertingkatkan profesionalisme keguruan masing-masing.

Kerangka kajian yang telah berjaya dibina akan dijadikan panduan kepada penyelidik melaksanakan kajian ini dengan lebih teratur dan bersestematik. Melihat tugas guru telah meluas sehingga kepengurusan organisasi sekolah, maka pengaruh teknologi akan meliputi dimensi pengurusan kerja sekolah dan proses pengajaran dalam pembelajaran di sekolah tertentu. Dengan cara ini, skop pengaruh teknologi di sekolah dapat dilihat dengan lebih tepat lagi memandangkan guru turut terlibat dengan pengurusan sekolah disamping penyampaian kurikulum. (Robert G. Murdick, 1997), dalam (Siti Magdalina, 2013).

Kajian-kajian lepas, teori dan model dalam kajian ini turut dijadikan panduan kepada penyelidik supaya lebih memahami skop kajian yang dikaji. Melihat kepada teori dan model telah memberikan satu gambaran tingkah laku individu, guru dalam konteks pendidikan, untuk mencapai matlamat atau prestasi yang baik dalam kerja atau tugas di sekolah amnya sebagai profesion keguruan yang mana begitu penting dalam era teknologi pendidikan masa kini.

\section{Rujukan}

Abd. Ghani Jaafar, How Lee Chan, K.Shoba A/P C. Karuppya, Bazrulzaman Baharom. (2005). Konsep dan Pelaksanaan Sekolah Bestari di Malaysia. Seminar pendidikan 2005, $\quad$ Fakulti Pendidikan UTM.

Bates, M, Manuel, S., dan Oppenheim, C. (2007). Models Of Early Adoption of ICT Innovations In Higer Education, Ariadne Issue 50 (atas talian) http://www.ariadne. ac.uk/issue50/oppenheim.et.al, Dicetak pada 23 Feb 2009, dalam Pang Shin Lu, 2010.

Carr, D. (2000). Professionalism and ethics in teaching. London:Routledge.

Chan Yuen Fook (1999). Teknologi maklumat dalam pendidikan di Malaysia. Jurnal pengurusan dan kepimpinan pendidikan Malaysia, 8(1).

Lay ,Y. F. \& Khoo, C. H. (2008). Pengenalan kepada analisis statistic dalam penyelidikan sains sosial . Siri 1. Everest Print:Venton.

Jabatan Aplikasi komputer dan jabatan korikulum dan korikulum IAB utara,(2007). Kerangka teori bagi mengimplementasi perubahan ict dalam pendidikan (atas talian http://www.iabu.moe.gov.my/AnalisisICT.pdf Dicetak pada 11/11/2013.

Khaziyati Osman. (2009). Tinjauan Keperluan Perkembangan Profesionalisme Guru Dalam Teknologi Maklumat Dan Komunikasi (ICT) Jurnal Pendidikan jilid 1 2008/2009 Jabatan Pelajaran Wilayah Persekutuan Labuan.

Kamisah Othman. (2006). Pembinaan intrumen untuk mengenalpasti tanggapan keperluan semasa guru-guru sains di Malaysia .Jil.21,101-113.Bangi:Universiti Kebangsaan Malaysia

Laila Hairani Bt. Abdullah Sanggura (2002). Professional development: Can the teachers's role be extended without loss of classroom competencies? Jurnal Pendidikan IPBA, 2(5): 63-71.

Mohd Majid Konting. (1990). Kaedah Penyelidikan Pendidikan Kuala Lumpur: Dewan Bahasa dan Pustaka.

Mohd Majid Konting. (2000). Kaedah Penyelidikan Pendidikan Kuala Lumpur: Dewan Bahasa dan Pustaka.

Mohd Najib Abdul Ghafar (1999). Penyelidikan Pendidikan. Skudai: Universiti Teknologi Malaysia.

Musa Abu Hasaan (2002). Peranan dan penggunaan ICT di kalangan masyarakat, Kuala Lumpur: Penerbit University Putra Malaysia Serdang. 
Noraini Ahmad. (2004). Peranan dan penggunaan ICT di kalangan masyarakat. Kuala Lumpur : Utusan Publication \& Distributors Sdn Bhd.

Pang Shin Lu. (2010). Inovasi Teknologi maklumat dan Komunikasi dengan Profesionalisme Keguruan. UMS.

Rahmat Sukor Ab. Samad (2005). Inovasi IT dalam pengurusan pendidikan .Sufean Hussin ,Shahril @ Charil Marzuki dan rakan -rakannya (ed.). pentadbiran dalam pembangunan pendidikan.Kuala Lumpur : PTS Profesional Publishing Sdn. Bhd. 2005.

Robert G. Murdick (1997). Persepsi Guru Terhadap Aplikasi Sistem Maklumat dalam Pengurusan Sekolah di daerah Beluran. SPPS. UMS.

Sonia Blandford (2010). Siri Kepimpinan dan Pengurusan Sekolah Panduan Pengurus Peringkat Pertengahan Di Sekolah Terjemahan Bahariah Yusuf. Institut Terjemahan Negara Malaysia dan Institut Aminuddin Baki.

Steven E. T,Guy S.,Paul C. (2006). School and society:Historical and Contemporary perspectives, $5^{\text {th }}$ edition. New York: McGraw Hill.

Steven, K.K. (2007). The successive use for information and communication technologies at work. Department of communication studies; university of texas. Pg 486-507. International communication association.

Woolfolk, A (2007). Education Psychology .Boston; Allyn \& Bacon.

Yuen. H.,K. (2003). ICT Implementation and school Leadership ,Case studies of ict integration in teaching and learning, journal od educational administration in teaching and learning. 